
PP-493 BPH/LUTS 患者に対するナフトピジル 75
23日(土) ポスター会場1 mg/日の投与方法に関する検討

\section{黒部市民病院泌尿器科1)，かみいち総合病院 ${ }^{2}$ ，済生会富山病院 泌尿器科 ${ }^{3}$}

釣 晋二(1), 奥村 昌央 ${ }^{2)}$, 野崎 哲夫 ${ }^{12}$, 木村 仁美 ${ }^{31}$, 風間 泰蔵) 【目的】我々は、BPH/LUTS 患者に対するナフトピジル (NAF) 75 $\mathrm{mg} /$ 日の投与方法について、夕分 1 投与が優れる可能性を報告し た (Tsuritani S, et al., Urol int, $2010 \mathrm{E}$-pub)。今回我々は、NAF $75 \mathrm{mg}$ 夕 1 投与がどのような症例に有効なのかを検討した。【方 法】 IPSS $\geqq 8 、 Q O L \geqq 2$ の BPH/LUTS 患者 101 例を、NAF 75mg/ 日の夕分 1 回投与 (夕 1 群) と朝昼夕 分 3 投与（分 3 群）に分 けて自覚症状、他覚所見、BII を検討した。結果】自覚症状、BII は両群ともに改善したが、Qave、残尿量は、夕 1 群のみであった。 排尿障害臨床試験ガイドラインに従い、改善例と不変例に分ける と、夜間排尿回数、BII 不快感は、夕 1 群ではともに有効であった が、分 3 群は改善例のみであった。改善例と不変例の投与前前立 腺体積は、夕 1 群では差はなく、分 3 群では改善群が有意に小さ かった。前立腺体積と Qmax は、夕 1 群は相関がなく、分 3 群は 有意な負の相関があった【結論】NAF75mgは、夕分 1 の方が、分 3 より有効性が高く、特に他覚所見の改善が必要な症例、夜間排尿 回数や不快感で困っている症例、前立腺の大きな症例には夕方 1 回投与が望ましい。

\section{PP-494 ナフトピジルの OABSS、IPSS における効果 23日（土）ポスター会場1の検討}

\begin{abstract}
昭和大学藤が丘病院泌尿器科 ${ }^{1)}$ ，麻生病院2)，横浜新緑総合病 院3)，小野寺クリニック ${ }^{4)}$, 深澤クリニック ${ }^{5)}$

太田 道也 ${ }^{17}$, 山本 健郎 ${ }^{17}$, 青木 慶一郎 ${ }^{12}$, 佐々木 春明 ${ }^{1)}$,

坂本 正俊 ${ }^{21}$, 石川 公庸 ${ }^{3)}$, 小野寺 恭忠 ${ }^{4)}$, 深澤 立 ${ }^{5}$,

後藤 隆太

対象は 21 年 2 月加 22 年 5 月に受診し、前立腺肥大症と診断されナフトピジル を处方した男性 55 例。年齢：68.4 7.2 歳、前立腺体積： $37.3 \pm 12.3 \mathrm{~g}$ 、残尿量 : $54.9 \pm$ $63.5 \mathrm{ml}$ であった。方法 投与前と投与後 4 週目、8 週目の OABSS, IPSS, QOL index および尿流率、残尿量を測定し投与後来院しなかった 1 例、有害事象発現 4 例その他 21 例を除き 38 例で比較し wilcoxon 検定で評価した。結果 OABSSでは投与前 $7.0 \pm 1.8$ で投与後 4 週目 $5.9 \pm 2.8(\mathrm{p}=0.271)$ と有意差は認めなかったが投与後 8 週日 $5.4 \pm 2.5(\mathrm{p}=0.015)$ と有意に改善をみとめた。IPSS では投与前 $17.6 \pm 6.9$ で投与後 4 週目 12.8 $\pm 5.5(\mathrm{P}<0.002)$ で投与後 8 週目 $12.2 \pm 5.2(\mathrm{p}<0.002)$ といずれも有意差を認 めた。IPSSにおいて排尿症状におけるスコアは投与前 $8.2 \pm 4.1$ で投与後 4 週目 $5.7 \pm$ $3.2(\mathrm{P}=0.003)$ で 8 週目 $5.2 \pm 3.0(\mathrm{p}<0.002)$ ともに有意差をみとめた。畜尿症状でも 投与前 $7.3 \pm 3.444$ 週目 $5.5 \pm 2.4(p=0.002) 、 8$ 週目 $5.4 \pm 2.3(p=0.002)$ でともに有意差 を認为た。夜間頻尿でも投与前 $2.6 \pm 1.5$ 投与 4 週目 $2.2 \pm 1.0(\mathrm{p}=0.006)$ 投与 8 週目 $2.0 \pm$ $1.2(\mathrm{p}=0.007)$ で有意差を認めた。QOL-index では投与前 $4.8 \pm 1.0$ でも投与後 4 週目 $3.8 \pm 1.1(\mathrm{p}=0.001)$ 投与後 8 週目 $3.9 \pm 1.1(\mathrm{p}=0.005)$ と有意に改善を認めた。ナフト ピジルでは、排尿症状を改善し夜間頻尿等の蓄尿症状を改善した。
\end{abstract}

\section{PP-495}

前立腺肥大症に対するナフトピジル（アビ 23日(土) ポスター会場 1 ショット) から塩酸タムスロシンへの変更症 例の検討

\section{横浜総合病院泌尿器科}

溝口 秀之, 志村 哲

【目的】 2010 年 3 月のアビショットの販売中止に伴い、前立腺肥大 症に対して治療薬を投与中の患者のうち、ナフトピジルから塩酸 タムスロシンンに変更を行った症例について臨床効果を検討し た。対象と方法】2009年 3 月〜2010 年 2 月の間に、当院でナフト ピジル $(50-75 \mathrm{mg})$ を塩酸タムスロシン $0.2 \mathrm{mg}$ に変更した 23 例について検討した。薬剤の変更前後で IPSS スコア、QOL スコ ア、最大尿流量、残尿量について統計学的検討を行った。変更後 8〜65 週で判定した。結果】ナフトピジルの投与期間は 63〜527 週であった。IPSS の合計は $12.2 \pm 5.3$ から $11.7 \pm 6.2(\mathrm{P}=0.602)$ 、 QOL スコアは $4.70 \pm 1.15$ から $4.39 \pm 1.3(\mathrm{P}=0.542)$ 、最大尿流量は $14.4 \pm 4.7 \mathrm{ml} / \mathrm{sec}$ から $14.3 \pm 6.5 \mathrm{ml} / \mathrm{sec}(\mathrm{P}=0.169)$ 、残尿量は $79.3 \pm$ $71.3 \mathrm{ml}$ から $94.1 \pm 98.5 \mathrm{ml}(\mathrm{P}=0.224)$ 、 と有意差はみられなかった。 副作用は特にみられなかった。結論】前立腺肥大症患者において、 ナフトピジルから塩酸タムスロシンへ変更しても、変更前後で IPSS スコア、QOL スコア、最大尿流量、残尿量に有意差はみられ なかった。塩酸夕ムスロシンに変更しても安全に同等の効果によ り継続できている。
PP-496 前立腺肥大症患者におけるナフトピジル 75 23日(土) ポスター会場 $1 \mathrm{mg}$ と塩酸タムスロシン $0.2 \mathrm{mg}$ の投与後早期 における比較検討（第 2 報）

\section{取手協同病院}

上原 翔, 松岡 陽, 奥野 哲男

【目的】ナフトピジル $75 \mathrm{mg}$ と塩酸タムスロシン $0.2 \mathrm{mg}$ の投与後 早期（1 日から 2 週間）に㧍ける有効性を比較検討した。方法】下 部尿路症状を主訴に来院した前治療無しの新規前立腺肥大症患者 （50 歳以上、前立腺体積 $20 \mathrm{ml}$ 以上、IPSS8 点以上）をナフトピジ ル投与群 (Naf 群) 15 例と塩酸夕ムスロシン投与群 (Tam 群) 10 例に無作為に割り付け、それぞれ $75 \mathrm{mg}$ と $0.2 \mathrm{mg}$ を 1 日 1 回、夕 食後に投与した。投与開始 1 日後、3 日後、7 日後、14 日後におけ る IPSS、QOL indexを用いて早期有効性の評価を行った。結 果】両群において投与翌日より IPSS 総スコアは有意に改善した。 また Naf 群において尿線途絶、腹圧排尿、残尿感の項目で投与翌 日より有意な改善がみられた。各時点において両群間に有意な差 異は認められなかった。両群ともに明らかな有害事象は認められ なかった【考察】ナフトピジル $75 \mathrm{mg}$ と塩酸タムスロシン $0.2 \mathrm{mg}$ は共に、投与翌日から自覚症状の改善が期待できる。

PP_497 前立腺肥大症に伴う排尿障害に対するナフト 23日 (土) ポスター会場1 ピジルとシロドシンのクロスオーバー試験

増田泌尿器科1), じんざクリニック 2), 朝倉医院泌尿器科 ${ }^{3)}$, ます こクリニッグ)，はしば泌尿器科皮膚科クリニック

増田 光伸 ${ }^{11}$, 神座 慎一郎 ${ }^{2)}$, 朝倉 智行 ${ }^{3)}$, 増子 洋 ${ }^{4)}$,

榛葉 隆文 ${ }^{-5)}$

【目的】ナフトピジル (Naf) とシロドシン (Silo) の無作為クロスオーバー試験 を行い、臨床的有効性について比較榆討を行った。更に今後どちらの薬剤の継続 を希望するか、また薬郕選択理由についてアンケート調查を行った【方法前立 腺推定体積が $20 \mathrm{~cm}^{3}$ 以上、IPSS が 8 点以上、QOL スコアが 3 点以上で、前立腺 肥大症と診断された未治療症例 40 例を対象とした。患者から同意書が得られた 症例を Naf 先行群とSilo 先行群に交互に割り付けした。Naf 回朝食後に投与、Silo は 1 回 $4 \mathrm{mg}$ を 1 日 2 回朝夕食後に投与した。先行薬剂を 6 週間投与後、wash out 期間を設けずもう一方の薬剤を 6 週間投与した。成續] 有效解析症例は 30 例であった。IPSS, QOL スコア, OABSS, IPSS の排尿症状, 畜尿症状, 夜間頻尿スコアは両薬剂共治療前と比べ有意に改善したが、薬剂間に 有意な差は認められなかった。有害事象は、Nafで4例、Siloで7例に見られた。 患者による薬片選択は、Naf 継続希望例が 12 例、Silo 希望例が 12 例、どちらで もないが6例であった。薬剂選択理由では Naf 希望例では「安全性」が、Silo 希望例では「効果の良さ」が最も多かった。結論] Naf とSilo は有效性において ほぼ同等であり、それぞれ有用性の高い薬剂である事が碓認された。薬郕選択に 対しては、各薬凨の特性を十分に説明し患者側の希望も考虑すべきと思われた。 